\title{
Ampulla of Vater Cancer Clinical TNM Finding v8
}

National Cancer Institute

\section{Source}

National Cancer Institute. Ampulla of Vater Cancer Clinical TNM Finding v8. NCI

Thesaurus. Code C134837.

A clinical finding about one or more characteristics of ampulla of Vater cancer, following the rules of the TNM AJCC V8 classification system. 